\section{Australian Journal of \\ Crop Science}

\title{
Effect of tear/crack on soybean (Glycine max) seed coat, physiological quality and pathology of the seed
}

\author{
Bruna Ribeiro Machado', Caio Cesar de Oliveira Pereira², Élida Priscila Bogéa Carvalho², Juliana Oliveira \\ da Silva ${ }^{2}$, Letícia Maria de Oliveira Mendes ${ }^{2}$, Milton Luiz da Paz Lima', Jakelinny Martins Silva ${ }^{2}$, Ivandilson \\ Pessoa Pinto de Menezes ${ }^{1^{*}}$
}

${ }^{1}$ Programa de Pós-Graduação em Proteção de Plantas, Instituto Federal Goiano, Urutaí, CEP: 75790-000, G0, Brazil

${ }^{2}$ Laboratório de Microbiologia, Instituto Federal Goiano, Urutaí, CEP: 75790-000, GO, Brazil

\section{*Corresponding author: ivan.menezes@ifgoiano.edu.br}

\begin{abstract}
Seed coat tear is frequently occurs in some soybean cultivars. The impact of seed coat tear on seed physiology and sanitation is uncertain. Our objective was to analyze the physiological and pathological effect of tear on soybean (Glycine max) seed coat. The cultivars NS-8338-IPRO (with high incidence of tear) and NS-6906-IPRO (with low incidence of tear) were used. A tetrazolium test was used to assess the physiological quality of the seed coat before and after storage. The sanitary quality was assessed through the "Blotter Test". For each storage period, we evaluated seeds with $0 \%$ coat tear, up to $10 \%$, and above $10 \%$. The experiment was performed in a completely randomized design using the methodologies proposed by RAS. The coat tear on soybean seed positively contributed to the moisture damage affecting the inner part of the seed. Incidences of Fusarium sp. and Aspergillus sp. were frequently observed in torn seeds and in seeds without tear (around 9-10\%) but did not interfere with seed quality. The appearance of coat tear on soybean seed is increased by moisture damage and do not serve as a gateway for the fungi to cause damage during seed emergence.
\end{abstract}

Keywords: Seed, Feature, Physiological evaluation, Sanitation evaluation, Fungi.

Abbreviations: RAS_Brazilian Seed Analysis Manual; NS_Nidera Seed; IPRO_Cultivars with intact technology; ANOVA_Analysis of Variance.

\section{Introduction}

Soybean seed (Glycine max) is a product of great technological importance in the productive system. Soybean is an important, innovative commodity in the agricultural market that allows farmers to reach maximum yields (Zhang et al., 2017). The quality of the seeds, which contributes to economic viability of the commodity, is determined by sanity, nutritional value, adaptation to the adverse climate and soil conditions, as well as greater genotype germination capacity (Krzyzanowski, 2016).

The high quality production is not an easy reachable aim, since germination can be affected by genetic factors, pest and microorganism attacks, mechanical damage during harvesting, processing and storage processes (Marcos-Filho, 2015). In addition, the seeds can serve as vehicles for dispersion of phytopathogenic agents and reduction of germination and vigor. They can be the primary foci for epidemic development. In soybean, some diseases cause concern because they can be economically catostrophic and are primarily transmitted by seeds (Goulart, 2005). Diseases of concern include: Anthracnose (Colletotrichum truncatum), purple seed stain (Cercospora kikuchii), frog eye leaf spot (Cercospora sojina), downy mildew (Peronospora manshurica), white mold (Sclerotinia sclerotiorum), phomopsis seed decay (Phomopsis spp.); bacterial pustule (Xanthomonas axonopodis pv. glycines), bacterial tan spot (Curtobacterium flaccumfaciens pv. flaccumfaciens), bacterial blight (Pseudomonas savastanoi pv. glycinea), wildfire of soybean (Pseudomonas syringae pv. tabaci); and Soybean Mosaic Virus (SMV). SMV is particularily of concern because it was introduced in Brazil through infected seeds (Wrather et al., 2010; Henning et al., 2014)

The seed coat has an important preventive role, as it is a protective wrap associated with vigor and longevity. Physical and physiological problems of the seeds are associated, contributing in large part, with the specific characteristics of the seed coat. For example, susceptibility to mechanical damage is associated with its lignin content, while the longevity and potential for deterioration on the field have been related to the degree of permeability of the seed coat (Souza and Marcos-Filho, 2001; Ma et al., 2004; Qutob et al., 2008). According to Mertz et al. (2009), due to a semipermeable coat, the seed has lower incidence of seedborne pathogens, lower rate of bedbugs' damage, greater storage potential, and greater resistance to mechanical damage. The seed also becomes less susceptible to deterioration. 
The coat tear/crack on soybean seed is defined as a physiological seed defect, verified in the reproductive phase R6. The tearing can be explained by seed coat crack on the dorsal side provoked by the rapid turgidity of the seed cells in function of the excess of water (Qutob et al., 2008; Senda et al., 2018). The tear is aggregated from moisture, but it does not arise from it. It may be initiated at the cotyledons, but with the advancement of storage and humidity to which the seeds are submitted in the field, the tear may be extended until the tip of the central cylinder. This can make the initial cells unfeasible which are important for the protrusion of the radicle (Huth et al., 2016; Zorato, 2017). According to the authors, other damages are observed in the coat seed such as stretch marks (which form smaller cracks in the coat), and cotyledons (or embryonic) axis wrinkles. Stretch marks are produced by excessive expansion and retraction of the cotyledons, especially during rainy periods near harvest. Cotyledon axis wrinkles can lead to reductions in vigor and viability depending on the depth of the formed groove.

Information about the effects of the coat tear on the soybean seeds is still incipient, showing the need for supplementary studies. Thus, this work was developed to test the hypothesis if the seed coat tear is causal for moisture degradation and fungi inoculation, and if this environment prevents vital germination and damages on germinative structures. The objective of this work was to evaluate the effect of coat tear on the pathology and physiological quality of soybean seeds. For this purpose, it was sought to determine the deterioration by moisture in the seeds with tear after harvest and after storage; and to determine the incidence of storage fungi and their influence on germination of teared seed.

\section{Results and Discussion}

Effect of the seed coat tear on moisture damage and physiological quality

Studies have shown that seed coat tear/crack may be related to the physical fatigue of the tissues in the final stage of maturation due to the changings of humidity and temperature of hot environments, which is typical of the tropical region of Brazil (Ma et al., 2004; Qutob et al., 2008; Forti et al., 2010; Senda et al., 2018). The tetrazolium test on soybean seeds in this study showed that the samples with coat tear/crack were progressively affected by moisture. This was more evident after the storage period, where there was a reduction of class without damage and consequent increase of the classes with damage (Table 2).

This result shows the influence of storage on the seed damage, even they do not show coat tear/crack. This observed in seeds with $0 \%$ of tear/crack where the percentage of seeds in the class was increased by $4.5 \%$ in Class 4-5 (represented by seeds with severe damages to the embryonic axis) and in 2\% of seeds in Class 6-8 (seeds already considered dead) with damages by moisture when submitted to storage. The same pattern of increase is more intense for the seeds in Classes 3, 4-5\% and 6-8\%, where the presence of a tear on the tegument is verified because they are more susceptible to the damage. The tear/crack becomes a gateway, or an 'entrance door', and facilitates damage, making much of the seeds unusable.
According to Forti et al. (2010) and Zorato (2017) combination of coat tear/crack at R6 stage, high humidity and temperatures make $80 \%$ of the seeds permeable. During this period, the coat tear provides increased moisture damage. In samples with more than $10 \%$ tear/crack before storage, it is assumed that humidity damage can already be present. This is mainly in the classes that prevent and diminish the vigor of the sample, increasing over six months of storage, as shown herein.

In all Class 2 to 8 , both before and after storage, we also observed a great occurrence of moisture damage (Table 3 ). Before storage, the sample with no tear/crack had the highest amount of moisture damage, maintaining high vigor and viability. This differed significantly from the other treatments. However, after 6 months of storage the damage on samples with $0 \%$ did not increase significantly. For the treatments of $10 \%$ and $>10 \%$ of tear, the amount of moisture damage was increased significantly. This increase in damage after storage did not present statistical difference between the treatments.

The total amount (in Classes 2-8) of moisture damage prior to storage was high, especially for the sample that did not contain coat crack. But the amount of moisture damage did not make the seeds unviable, as the damage was concentrated in Class 2, where seed vigor is still considered high. After the storage period, the moisture damage was increased as expected. Yet, the sample that did not contain tearing or biotic and abiotic damages remained viable and vigorous though the seeds mostly evolved to Class 3 . However, seeds with tearing, mainly $>10 \%$, had reduced vigor and viability because the seeds began storage at a Class 3 (medium vigor) but the damage increased making the seeds a Classes 4-5 (low level of vigor). Forti et al. (2010) observed that the seed batch with the lowest physiological potential before storage had one of the highest occurrence and increase of moisture damages. Moisture damage on seeds classified as Class 4-5 (Table 4) showed a significant difference between the pre- and post-storage conditions. However, there was no significant difference between the $0 \%, 10 \%$, and $>10 \%$ treatments.

After storage of non-viable seed classes (Classes) 6-8, the sample that did not contain tearing did not show a significant increase of dead seeds (Table 5). For the samples with tear on seeds $<10 \%$ and $>10 \%$, the difference was significant. Before storage the number of dead seeds in the treatments were statistically the same, but after 6 month of storage the sample $>10 \%$ differed significantly from the others, presenting a larger number of seeds killed by the moisture damage. Forti et al. (2010) observed that during storage moisture damage was increased in Classes 1-8, which is due to damage only being present in the coat and not the cotyledons. During the storage period these possible micro-damages favored seed deterioration in the cotyledons making the symptoms of moisture damage visible in later evaluations.

By moisture damages observed in Classes 6-8 and the presence of dead seeds, we can compare the viability of the samples, since the viable seeds fit into Classes 1-5 (Table 1). It was noted that the viability of the sample (Table 6) with $0 \%$ tear did not change significantly after storage, but for the $10 \%$ and $>10 \%$ tear treatments the viability decreased significantly after storage. Comparison of treatments before 
Table 1. Classes grades attributed to the levels of moisture damages observed in soybean seeds through the tetrazolium test.

\begin{tabular}{lll}
\hline Classes & Damage Level & Seed Vigor \\
\hline 1 & Not observed & Higher vigor \\
2 & Not severe & High vigor \\
3 & Severe & Medium vigor \\
4 and 5 & Severe, affecting embryonic axis & Low vigor \\
$6-8$ & Dead & Not feasible \\
\hline
\end{tabular}

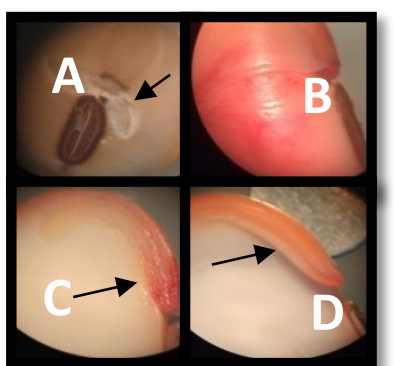

Fig 1. Tear on the seed coat of soybean and moisture damage demonstrated by tetrazolium test. A. Position of the tear on the seed, above embryonic axis. B. Seed colored (Red color) by tetrazolium salt. C. Moisture damage in the embryonic axis. D. Embryonic axis without damage.

Table 2. Percentage of seeds in each treatment $(T)$ classified by the level of moisture damage using tretrazolium test before and after storage.

\begin{tabular}{|c|c|c|c|c|c|c|c|c|c|c|}
\hline \multirow{3}{*}{$\mathrm{T}$} & \multicolumn{10}{|c|}{ Classes attributed to the levels of moisture damages } \\
\hline & \multicolumn{2}{|c|}{ Class 1} & \multicolumn{2}{|c|}{ Class 2} & \multicolumn{2}{|l|}{ Class 3} & \multicolumn{2}{|c|}{ Class 4-5 } & \multicolumn{2}{|c|}{ Class 6-8 } \\
\hline & Before & After & Before & After & Before & After & Before & After & Before & After \\
\hline $0 \%$ & 10.5 & 2.5 & 69.75 & 51.5 & 17.75 & 36.5 & 1.5 & 6 & 0.5 & 3.5 \\
\hline$<10 \%$ & 15.75 & 5 & 49.25 & 50.25 & 32.5 & 33.7 & 1.5 & 5.5 & 1 & 5.5 \\
\hline$>10 \%$ & 39.5 & 11.5 & 14 & 27.75 & 45 & 37.25 & 1 & 10 & 0.5 & 13.5 \\
\hline
\end{tabular}

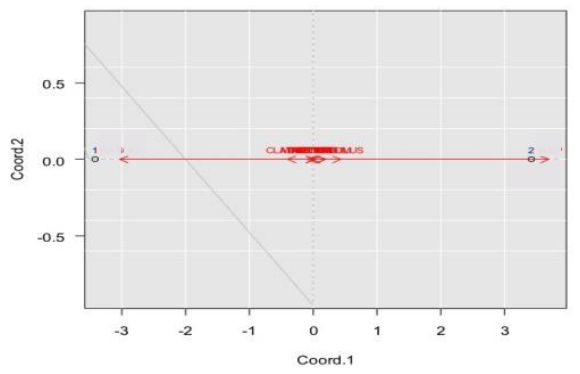

Fig 2. Coat tear and ASP (incidence of Aspergillus) had a greater effect on the differentiation between the NS8338 IPRO (1) and NS6906 IPRO (2) cultivars analyzed using Principal Components Analysis (PCA).

Table 3. Mean comparisons between treatments of total moisture from Classes 2-8 before and after storage.

\begin{tabular}{|c|c|c|c|c|}
\hline \multirow{3}{*}{ Condition (C) } & \multicolumn{4}{|c|}{ Moisture Unfolding Analysis Classes 2-8 } \\
\hline & \multicolumn{3}{|c|}{ Treatment $(\mathrm{T})$} & \multirow{2}{*}{$\mathrm{F}(\mathrm{C})$} \\
\hline & $0 \%$ of tear & $10 \%$ of tear & $\geq 10 \%$ of tear & \\
\hline Before Storage & 89.5 a A & $84.25 \mathrm{~b} \mathrm{~A}$ & 60.5 b B & $32.10^{*}$ \\
\hline After Storage & 97.5 a $A$ & 95 a $A$ & 88.5 a $A$ & $2.90^{\mathrm{ns}}$ \\
\hline$F(T)$ & $0.05^{\mathrm{ns}}$ & $7.76^{*}$ & $52.70 *$ & \\
\hline
\end{tabular}

${ }^{1}$ Means followed by the same letter in the column (lower case) and line (upper case) do not differ statistically from each other by the Tukey test ( $\left.\mathrm{P}>0.05\right)$.

Table 4. Average number of moisture damages for the treatments without and with tear in class 4-5, before and after storage.

\begin{tabular}{lc}
\hline Factor (S) - Storage & Moisture 4-5 \\
\hline Before Storage & $1.33 \mathrm{~b}$ \\
After Storage & $7.16 \mathrm{a}$ \\
$\mathrm{F}(\mathrm{S})$ & $44.7^{*}$ \\
$\mathrm{P}$-value $(\mathrm{S})$ & 0 \\
\hline Factor $(\mathrm{T})$ - Treatment & $3.75^{\mathrm{a}}$ \\
\hline $1-0 \%$ tear & $3.5^{\mathrm{a}}$ \\
$2-10 \%$ tear & $5.5^{\mathrm{a}}$ \\
$3-\geq 10 \%$ tear & $2.08^{\text {ns }}$ \\
$\mathrm{F}(\mathrm{T})$ & 0.15 \\
$\mathrm{P}$-value (T) & $3.32^{\text {ns }}$ \\
\hline $\mathrm{F}(\mathrm{S} \times \mathrm{T})$ & 0.06 \\
$\mathrm{P}$ valor $(\mathrm{S} \times \mathrm{T})$ & 50.28 \\
CV $(\%)$ &
\end{tabular}


storage showed that viability was high, not differing from each other. However, after storage the seed samples with coat tear/crack on seeds differed statistically from the samples that did not contain coat tear.

The most important parameter observed for the evaluation of the physiological quality of the sample was the vigor, since it was used to classify seeds of Class 1,2 and 3, classified with high to medium vigor (Table 1). It was observed that the vigor of the samples both inside and between treatments with $0 \%,<10 \%$ and $>10 \%$ of tear on seeds were decreased only after the period of six months of storage, differing statistically (Table 7).

The low vigor and the high number of non-viable seeds with high tear percentage are due to the more severe damage in the inner part of the seed, near or even crossing the embryonic axis of the seed (Fig 1). This higher intensity of damage may be related to the position of the coat tear/crack on top of the embryonic axis, providing the entry of moisture into the cotyledons. Zorato (2017) claimed that coat tear is not an innocent defect. It may first exist only at the cotyledons, but with the advancement of storage and depending on the moisture content the seeds may extend to the tip of the central cylinder and impaire the early cells. This is important for the radicle protrusion as prompted by the finding of progressive moisture damage demonstrated in this study at in vitro conditions.

\section{Analysis of the seed coat tear/crack on the pathogen incidence}

Evaluation of dependent variables showed that only ERP\% presented normal distribution (Table 8 ). The other variables studied were not normally distributed, requiring a nonparametric hypothesis test.

The NS-8338-IPRO cultivar had a higher percentage of coat tear (37\%) when compared to the cultivar NS-6906-IPRO $(17 \%)$, where they showed no significant difference in the physiological activity, nor as much as incidences of the microorganism complex (IM). The genus of fungi presented in NS-8338-IPRO cultivar were Fusarium sp., Penicillium sp., Aspergillus sp., Cladosporium sp., Macrophomina sp., Trichoderma sp., and Mucor sp., in addition to bacteria. Fungi in cultivars NS-6906-IPRO were identified as Phytium sp., Myrothecium sp., and Rhizoctonia sp. Aspergillus sp. and Bacillus sp. (Table 8). The NS-8338-IPRO cultivar showed the lowest incidence for ASP and BAC, at $27.4 \%$ and $0.2 \%$, while the cultivar NS-6906-IPRO had a higher incidence, $52.8 \%$ and $3.2 \%$, respectively.

The genus species Aspergillus can reduce the germinative power of the seeds under high humidity conditions and at high incidence of mechanical damage from the tear (Goulart, 2005; Mannaa and Kim, 2017). Aspergillus is an important storage fungus. Guimarães et al. (2017) found that damage caused by pathogens may be directly related to the potential of inoculum and location in the seed (internal or external), with a greater concern if this location is close to the embryo. Even if the fungi do not cause immediate damage, there are latency relationships, which are cumulative during storage. Consequently, lack of control can trigger deterioration of seeds because these damages can be the gateway for different species of Aspergillus and Penicillium. These fungi develop under high temperature and relative humidity but are also able to survive in low humidity environments. They proliferate in succession to field fungi, causing seed deterioration (Bennett, 2010). This emphasizes the importance of the presence and location of the tear/crack on the seed coat. Even if the NS-6906 cultivar presented the lowest percentage of tear and the highest incidence of Aspergillus, these effects were not determinant to affect the primary root emission (98.4\%) (Table 8).

Although the incidence of Fusarium, Penicillium, and Cladosporium was slightly higher in the cultivar NS-8338IPRO $(10.6 \%, 2.2 \%$, and $4.8 \%)$ than cultivar NS-6906-IPRO $(9 \%, 1.6 \%$, and $2 \%)$ they were not significantly different (Table 8). However, this slight increase may indicate existaence of threats in normal conditions other than in vitro. The genus Fusarium is a dominant fungus, but among the pathogenic fungi found in field mold infection was prevalent during seed development (Liu et al., 2017). That causes germinative damage, wilt, and decay in pre- and post-emergence in the field (Henning, 2014).

The fungi belonging to Pythium sp., Myrothecium sp. and Rizoctonia sp. presented a unique occurrence in the cultivar NS-6906-IPRO, although in a low percentage. Myrothecium is a soil and saprophytic fungus with wide dispersion in temperate and tropical regions that survives in cultural remains. It is present in a range of hosts including legumes, solanaceae, and cucurbitaceae. It can be transmitted by seeds (Henning, 2014). Therefore, it is a fungus that cannot be ignored when detected in the seeds for sowing. The same alert can be made regarding the presence of Rhizoctonia solani in soybean. $R$. solani can cause damping off in seedlings and adult plants and Phythium the disease denominated of Leaf blight during the flowering period (Henning, 2014). Phythium produces root, stems, and fruits rot, pre-emergence seed rot, and post-emergence seedling damping off (Kirk et al., 2008).

Finally, the fungi belonging to Macrophomina sp. occurred only in NS-8338-IPRO. These fungi are not a problem for the soybean seeds cultivars. According to Henning (2014), the pathogen occurs quite frequently in dry climate situations and in plants with a superficial root system derived from soil compaction. Though not the main source, its transmission via seed can occur since the Brazilian soils naturally contain this pathogen.

Genotype NS-8338-IPRO (Treatment 1), presented the highest percentage of coat tear and genotype NS-6906-IPRO (Treatment 2), presented the highest incidence of Aspergillus by correlations of Principal Component Analysis (Fig 2).

Soybeans in the field are attacked by a large number of fungal diseases, which can cause damage to both the yield and the quality of the seeds. The seeds mostly transmit these fungal diseases. Thus, from the sanitary point of view, the ideal seed is a seed free from any undesirable microorganism (Goulart, 2005). The present work showed that even in seeds with coat tear/crack, pathological microorganisms did not prevent primary root emergence, since ERP\% was high for both cultivars and did not show significant difference.

Evaluating the incidence of fungi on the seeds is of great importance, since after sowing the seeds will deteriorate in the soil if it is dry, very humid, or cold. If these adverse conditions are imposed to the seeds, the germination speed is reduced and the emergence of seedlings is affected. The seed can then be exposed to the harmful action of soil fungi, such as Aspergillus spp., Fusarium spp., Rhizoctonia solani, Sclerotium rolfsii and Pythium spp. (Henning, 2014; Mannaa 
Table 5. Values of conditions and percentages of the tear interaction referring to the amount of damage by the moisture in classes 6-8.

\begin{tabular}{lllll}
\hline \multirow{2}{*}{ Condition (C) } & \multicolumn{4}{c}{ Moisture Unfolding Analysis Classes 6-8 } \\
\cline { 2 - 5 } & \multicolumn{4}{c}{ Treatment ( T ) } \\
\cline { 2 - 4 } & $0 \%$ of tear & $10 \%$ of tear & $\geq 10 \%$ of tear \\
\hline Before Storage & 0.5 a A & $1 \mathrm{~b} \mathrm{~A}$ & $0.5 \mathrm{~b} \mathrm{~A}$ & $0.04^{\mathrm{ns}}$ \\
After Storage & $3.5 \mathrm{a} \mathrm{B}$ & $5.5 \mathrm{a} \mathrm{B}$ & $13.5 \mathrm{a} \mathrm{A}$ & $16.60^{*}$ \\
\hline $\mathrm{F}(\mathrm{T})$ & $0.12^{\mathrm{ns}}$ & $6.00^{*}$ & $50.11^{*}$ & \\
\hline
\end{tabular}

Table 6. The conditions and percentages of the tear interaction, referring to samples viability.

\begin{tabular}{|c|c|c|c|c|}
\hline \multirow{3}{*}{ Condition (C) } & \multicolumn{4}{|c|}{ Viability Analysis } \\
\hline & \multicolumn{3}{|c|}{ Treatment ( T ) } & \multirow{2}{*}{$F(C)$} \\
\hline & $0 \%$ of tear & $10 \%$ of tear & $\geq 10 \%$ of tear & \\
\hline Before Storage & 99.5 a $\mathrm{A}$ & 99 a $\mathrm{A}$ & 99.5 a $\mathrm{A}$ & $0.04^{\mathrm{ns}}$ \\
\hline After Storage & 96.5 a $A$ & $94.5 \mathrm{~b} \mathrm{~A}$ & 86.5 b B & $16.60 *$ \\
\hline $\mathrm{F}(\mathrm{T})$ & $0.12^{\mathrm{ns}}$ & $6.00 *$ & $50.11 *$ & - \\
\hline
\end{tabular}

Table 7. Analysis of the conditions and percentages of the tear interaction, referring to samples vigor.

\begin{tabular}{lllll}
\hline \multirow{2}{*}{ Condition (C) } & \multicolumn{4}{c}{ Vigor Analysis } \\
\cline { 2 - 5 } & \multicolumn{4}{c}{ Treatment ( T ) } \\
\cline { 2 - 5 } & $0 \%$ of tear & $10 \%$ of tear & $\geq 10 \%$ of tear & F (C) \\
\hline Before Storage & $98 \mathrm{a} \mathrm{A}$ & $97.5 \mathrm{a} \mathrm{A}$ & $98.5 \mathrm{a} \mathrm{A}$ & $0.15^{\mathrm{ns}}$ \\
After Storage & $90.5 \mathrm{~b} \mathrm{~A}$ & $89 \mathrm{~b} \mathrm{~A}$ & $76.5 \mathrm{~b} \mathrm{~B}$ & $35.45^{*}$ \\
\hline $\mathrm{F}(\mathrm{T})$ & $16.87^{*}$ & $21.67^{*}$ & $145.2^{*}$ & - \\
\hline
\end{tabular}

${ }^{1}$ Means followed by the same letter in the column (lower case) and line (upper case) do not differ statistically from each other by the Tukey test $(\mathrm{P}>0.05)$.

Table 8. Averages of tear\%, of primary root emission (ERP\%),\% of incidence of microorganisms (IM), \% incidence of Fusarium sp. (FUS), \% of incidence of Penicillium sp. (PENI), \% of incidence of Aspergillus sp. (ASP), \% of incidence of Cladosporum sp. (CLAD), \% of incidence of Bacillus sp. (BAC), \% of incidence of Macrophomina phaseolina (MACRO), \% of incidence of Trichoderma sp. (TRIC), \% of Mucor sp. (MUC), \% of Pythium sp. (PYT), \% of Myrothecium sp. (MYR), \% of Rhizoctonia incidence (RIZOC) and parameters of parametric and non-parametric analysis submitted to two soybean cultivars by Blotter test.

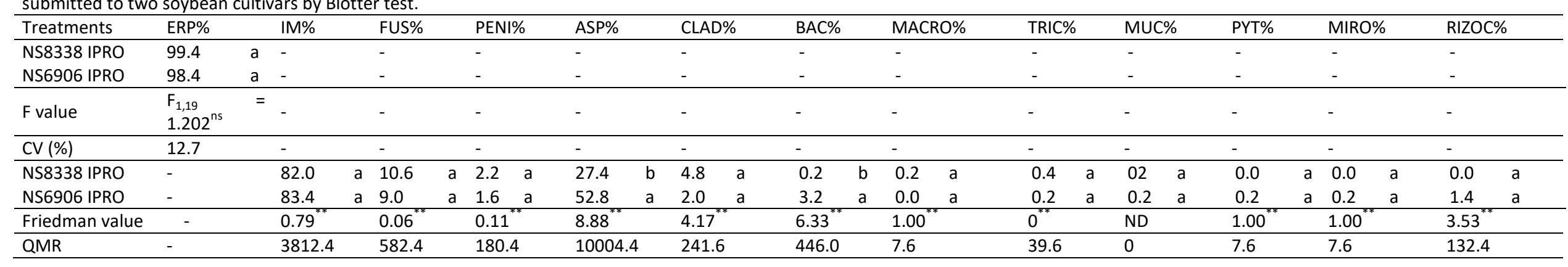


and Kim, 2017). Based on main Principal Component Analysis, we verified that the coat tear was more responsible for the results obtained for NS-8338-IPRO and the incidence of Aspergillus sp. in NS-6906-IPRO (Fig 2).

\section{Materials and methods}

\section{Conduction of study}

The research was conducted at the Seeds Laboratory, at Nidera Seeds Company, in Cristalina city - Goiás, Brazil, and at the Phytopathology Laboratory, at Instituto Federal Goiano Campus Urutaí, Goiás.

\section{Plant materials}

The soybean genotype selected for the study of physiological quality was NS-8338-IPRO, due to the high tear rate presented shortly after harvest (37\%). This genotype has the Intacta RR2-PRO ${ }^{\text {TM }}$ technology (http://www.niderasementes.com.br/conteudo/tecnologia-soja.aspx), which controls for Velvetbean caterpillar (Anticarsia gemmatalis), Soybean looper moth (Chrysodeixis includens and Rachiplusia nu) and Tobacco budworm (Heliothis virescens). It also can suppress damage by the Lesser Cornstalk Borer (Elasmopalpus lignosellus), Old World (African) bollworm (Helicoverpa armigera) and Corn earworm (Helicoverpa zea). Besides these attributes. it also has tolerance to the herbicide glyphosate, determined growth, high yielding capacity, and its population can be 280 to 320 thousand plants / ha, depending on the altitude.

For the evaluation of the effect of the coat tear/crack on the seed pathology, two genotypes of the Nidera Seeds Company were selected. These genotypes were NS-8338IPRO (cultivar with the highest tear incidence) and NS-6906IPRO (cultivar with lowest tear index and an architecture favorable to disease control), besides having excellent grain weight, high productivity, with indeterminate growth. Its population can vary from 300 to 420 thousand plants/ha depending on the region.

\section{Treatments}

The seeds were evaluated immediately after harvesting and processing (April 2017). The storage was done for six months (October 2017) in refrigerated warehouses with controlled

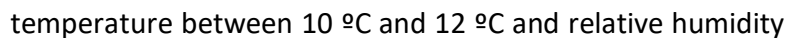
between $50 \%$ and $60 \%$. All seeds had pre- (PrS) and poststorage (PS) treatments, respectively. These treatments were imposed to analyze the evolution, or increase of the damage by moisture that is stored between the period of the beneficiation until the seed sowing.

For each storage period, we evaluated seeds with $0 \%$ coat tear, up to $10 \%(<10 \%)$, which is Nidera Seeds Company's minimum limit tolerance, and above $10 \%(>10 \%)$, which is not tolerated. The percentage of tear on tegument was determined from a sample of $1 \mathrm{~kg} / \mathrm{each}$ lot, taking two replicates of 100 seeds. The criteria used to determine the percentage were established by Nidera Seeds Company.

\section{Experimental design and traits measured}

The experimental design was a completely randomized design, and the procedures for evaluating physiological quality and seed pathology were performed according to RAS - Brazilian Seed Analysis Manual (Mapa, 2009). The evaluation of effect of coat tear on the moisture deterioration process in soybean seeds was performed before and after storage using the tetrazolium test with tears of $0 \%, 10 \%$ and $>10 \%$. This test allowed us to evaluate the viability and vigor of the seed lot, besides informing about possible damages, such as bedbug damage, mechanical damage and moisture damages (França Neto et al., 1998).

For the tetrazolium test, a total of 200 seeds/treatment was used, being 4 replicates of 50 seeds/each. The seeds tested were preconditioned on moist 'germitest paper', with water equivalent to 2.5 times of their weight for 16 hours at room temperature. Then the seeds were placed in Becker's with a solution of $0.1 \%$ concentration of 2,3,5-triphenyl-tetrazolium chloride. They were then kept in the dark in a greenhouse at $35{ }^{\circ} \mathrm{C}$ for 3 hours for color development and washed in running water for evaluation.

The seeds were evaluated one by one by being cut longitudinally through the center of the embryonic axis with the aid of a razor blade. The halves were separated and the tegument was removed so that the external surface of the cotyledons was exposed. Thus, moisture damage was observed and classified according to the staining pattern and notes by França Neto et al. (1998) (Table 1). After the evaluation, the percentage of seeds classified at each level of viability was determined, calculating the germination potential (sum of the values classified in Classes 1 to 5) and vigor (sum of Classes 1 to 3 ). The percentages of the damage due to moisture were also calculated for Classes 1-8 and 6-8, and in each sub-sample the number of seeds that presented the damage by moisture was multiplied by two to obtain the percentage value, then the mean of the two replicates calculated.

The analysis of the seed pathology was done in Blotter Test with 10 replications/cultivar. The non-disinfested seeds were arranged individually on a layer of moistened filter paper (two sheets of blotting paper) in Gerbox, keeping them spaced $1-2 \mathrm{~cm}$ apart. The seeds were incubated in 12-hour photoperiod growth chambers for a 7-8 days period at \pm 22 ${ }^{\circ} \mathrm{C}$. Then the seeds were examined individually using a stereomicroscope, resolution of $30-80 \mathrm{X}$, for the occurrence of fungi growth. Optical microscope slides were prepared for observation. Thus, germination percentage (G\%) was the number of germinated seeds (epicotyl/radicle emission) by the total number of seeds per Gerbox (variable dependent on physiology). The percentage of pathogen incidence (IP\%) was calculated from the count of the number of seeds that had structures of microorganisms on their surface divided by the total number of seeds evaluated by Gerbox (variable depends on sanitary conditions). The percentage of pathogen genera (GP\%) was identified and calculated by counting the genotypes of the fungi identified in the seeds divided by the total number of seeds by Gerbox (variable depends on sanitary conditions). The incidence of microorganisms was individually analyzed. 


\section{Statistical analysis}

The residues from the data analysis were tested for normality and homoscedasticity. Then, the data was analyzed through analysis of variance (ANOVA) and the means were compared by the Tukey's HSD test at a 95\% confidence level. When the assumptions did not hold, the data was submitted to a non-parametric analysis of the Friedman test, at $95 \%$ confidence level using the statistical package $\mathrm{R}$ Software. We also performed a Principle Component Analysis (PCA) of main features for all the dependent variables to differentiate the soybean cultivars.

\section{Conclusion}

The coat tear on soybean seed contributes to the damage by moisture affecting the internal part of the seed, damaging the embryonic axis, and making the seed less vigorous and even unviable. The occurrence of Fusarium sp. and Aspergillus sp. is relevant for seeds with tear and seeds without tear (around 9-10\%), but the fungi does not affect seed quality. The other genera of fungi identified in the seeds (Penicillium sp., Cladosporium sp., Trichoderma sp., Mucor sp., Macrophomina sp., Phytium sp., Myrothecium sp. and Rhizoctonia sp.) present low incidence, and even with the presence of the coat tear on soybean seed these fungi do not affect the emission of the primary root. Thus, the coat tear on soybean seed is not a gateway for fungi to affect seed emergence.

\section{Acknowledgments}

We thank to Nidera Seeds by allowing us to use the company facility for the development of this work and to the Instituto Federal Goiano Campus Urutaí, Brazil through financial assistance. To Melinda Knuth, Horticulture PhD Student of the Texas A\&M University for her English revision work.

\section{Conflicts of interest}

The authors declare that no conflicts of interest exist.

\section{References}

Bennett JW (2010) An overview of the genus Apergillus. In: Machida M, Gomi K (ed) Aspergillus molecular biology na genomics. Caister Academic Press, Norfolk.

Forti VA, Cicero SM, Pinto TLF (2010) Avaliação da evolução de danos por "umidade" e redução do vigor em sementes de soja, cultivar TMG113-RR, durante o armazenamento, utilizando imagens de raios $x$ e testes de potencial fisiológico. Rev Bras Sementes. 32(3):123-133.

França Neto JB, Krzyzanowski FC, Costa NP (1998) The tetrazolium test for soybean seeds. Embrapa Soja, Londrina (Embrapa Soja. Documentos, 115) 71 p. https://core.ac.uk/download/pdf/15445829.pdf (Accessed March 19, 2017)

Goulart ACP (2005) Fungos em sementes de soja: detecção, importância e controle. In: Goulart ACP (ed) Fungos em sementes de soja: detecção e importância. Embrapa Agropecuária Oeste, Dourados. p 72.
Guimarães MRF, Siqueira CS, Machada JC, França SKS, Guimarães GC (2017) Evaluation of inoculum potential of pathogens in seeds: relation to physiological quality and DNA quantification by qPCR1. J Seed Sci. 39(3):224-233.

Henning AA, Almeida AMR, Godoy CV, Seixas CDS, Yorinori JT, Costamilan LM, Ferreira LP, Meyer MC, Soares, RM, Dias WP (2014) Manual de identificação de doenças de soja. $5^{a}$ ed. Embrapa-Soja, Londrina.

Huth C, Mertz-Henning LM, Lopes SJ, Tabaldi LA, Rossato LV, Krzyzanowski FC, Henning FA (2016) Susceptibility to weathering damage and oxidative stress on soybean seeds with different lignin contents in the seed coat. J Seed Sci. 38(4):296-304.

Kirk PM, Cannon PF, Minter DW, Stalpers JA (2008) Dictionary of the Fungi. CABI Europe, Wallingford.

Krzyzanowski FC (2016) Características físicas da semente: dano mecânico não aparente, densidade e peso de 1000 sementes. In: Lorini I (ed) Qualidade de sementes e grãos comerciais de soja no Brasil - safra 2014/15. Embrapa Soja, Londrina. p 4957.

Liu J, Deng J, Yang C, Huang Ni, Chang X, Zhang J, Yang F, Liu W, Wang X, Yong T, Du J, Shu K, Yang W (2017) Fungal diversity in field mold-damaged soybean fruits and pathogenicity identification based on high-throughput rDNA sequencing. Front Microbiol. 8:1-11.

Ma F, Cholewa E, Mohamed T, Peterson CA, Gijzen M (2004) Cracks in the palisade cuticle of soybean seed coats correlate with their permeability to water. Ann Bot. 94:213-228.

Mannaa M, Kim KD (2017) Influence of temperature and water activity on deleterious fungi and mycotoxin production during grain storage. Micobiology. 45(4):240-254.

Mapa (2009) - Ministério da Agricultura, Pecuária e Abastecimento. Regras para análise de sementes. Brasília. http://www.agricultura.gov.br/assuntos/insumosagropecuarios/arquivos-publicacoesinsumos/2946_regras_analise_sementes.pdf (Accessed June 20, 2017)

Marcos-Filho, J (2015) Seed vigor testing: an overview of the past, present and future perspective. Sci Agric. 72(4):363-374.

Mertz LM, Henning FA, Cruz HL, Meneghello GE, Ferrari CS, Zimmer PD (2009) Diferenças estruturais entre tegumentos de sementes de soja com permeabilidade contrastante. Rev Bras Sementes. 31(1):023-029.

Qutob M, Ma F, Peterson CA, Bernards MA, Gijzen M (2008) Structural and permeability properties of the soybean seed coat. Botany. 86:219-227.

Senda $M$, Kawasaki M, Hiraoka M, Yamashita K, Maeda $H$, Yamaguchi $N$ (2018) Occurrence and tolerance mechanisms of seed cracking under low temperatures in soybean (Glycine max). Plant. 248:369-379.

Souza FHD, Marcos-Filho J (2001) The seed coat as a modulator of seed-environment relationships in Fabaceae. Braz J Bot. 24 (4): $365-375$.

Zhang Q, Li Y, Chin KL, Qi Y (2017) Vegetable soybean: Seed composition and production research. Ital J Agron. 12:276282.

Zorato MF (2017). Evolução do laboratório de análise de semente. SEED News. 2: 24-29.

Wrather A, Shannon G, Balardin R, Carregal L, Escobar R, Gupta GK, Ma Z, Morel W, Ploper D, Tenuta A (2010) Effect of diseases on soybean yield in the top eight producing countries in 2006. Plant Health Prog. doi: 10.1094/PHP-2010-0125-01RS. 